\title{
Exploring the Causes, Impacts and Mediums of Ethnocentrism: The Case of Selected Zones of South Nation Nationalities and Peoples Region, Ethiopia
}

\author{
Dawit Ashuro* \\ Department of Psychology, Wachemo University, Ethiopia
}

Submission: June 18, 2021; Published: July 01, 2021

*Corresponding author: Dawit Ashuro, Department of Psychology, Wachemo University, Ethiopia

\begin{abstract}
Ethnocentrism has been the most constant social problem and as such, living together in a harmonious society with different ethnic backgrounds, culture, language, and religion has not been easy for society. The objective of this study was be to explore the causes, impacts, and mediums of ethnocentrism on societies in selected zones of South Nation Nationalities and Peoples Region. The study used a combination of purposive, stratified and simple random sampling techniques to select 3 zones, 343 respondents to represent the total population as a sample. Both quantitative and qualitative data were collected using two separate instruments, questionnaire and focus group discussion. Data was analyzed and presented in descriptive statistics and inferential statistics. Frequency, percentage, and mean were used to analyze quantitative data about causes, effects, and mediums of ethnocentrism. Independent sample t-test was used to analyze sex difference between male and female respondents in their ethnocentric attitudes. One way ANOVA was employed to examine the differences in demographic variables (age, experience, educational level, and marital status) in the scores on respondents' ethnocentric attitudes. From the analysis, the following findings were identified. Political factors are the most serious causes of ethnocentric attitudes. The leading effects of ethnocentrism were national agenda narrowed and replaced by ethnic agenda, property loss, and making false assumptions about others. Ethnocentric attitudes were enforced by wrong use of agenda of ethnic parties, ethnic federalism, social media, ethnic literatures, and ethnic based sport clubs. Based on the findings of the result, the present study provided recommendations for the concerned stake holders to reduce ethnocentrism.
\end{abstract}

Keywords: Ethnocentrism; Causes of ethnocentrism; Effects of ethnocentrism; Mediums of ethnocentrism

\section{Introduction}

For a nation with a multi-ethnic composition of the population, a more encouraging situation such as peace, solidity and harmony are desired in the society. As stated by Raha Radzi [1], social solidarity is an important pillar in building harmonious ethnic relations in a plural society. National unity among the ethnics is very important to ensure national harmony. Rapid growth and development in a country does not bring anything if people were not united. Ethnocentrism is one of the most influential factors that affect solidarity and harmony in the society [2]. This is high in multiethnic countries [3].

According to Njoroge and Krori (2013) ethnocentrism is a mental and psychological state, which revolves around the belief that one's ethnic group is much more central, than the ethnic groups of others. This is to mean that, an ethnocentric person judges others from other ethnic groups, according to the view and belief-system, of his or her own (ethnocentric) ethnic group, relating to spoken-language, behavioural-system, religion, population size, and custom affiliation. As cited in Njoroge and Krori, 2013, Professor William G. Summers [4] the first professor of sociology at the Yale College, in the United States of America explained ethnocentrism, to mean, the technical name in one's own perspective, and in which one's own ethnic group is the beginning and end of everything, and that, all other ethnic groups must be measured according to the tenets and belief-system of his or her own (ethnocentric) ethnic group.

As discussed by Syed Husin Ali (2008), national stability seems to have reduced increasingly because of these ethnic attitudes, which regularly manifest in prejudices, tensions, discriminations 
and conflicts that cause problems to the development of the country and constructing national harmony. A research done by Jusang Bolong et al. [5] also shows that individuals like to interact with their own ethnic group rather than interacting with people from other ethnic groups. In addition, as stated by Mohd Ridhuan Tee [6], communications among ethnic groups in Malaysia have decreased because of practicing ethnic settlements. This can cause the ethnocentrism to be stronger. Ethnocentrism can form hurdles to communication with those who are culturally different and thus make it difficult to achieve unity among ethnics.

Research conducted by Mustapha, et al. [7] reveal that ethnocentrism has been the most constant social problem and as such, living together in a harmonious society with different ethnic backgrounds, culture, language, and religion has not been easy for society. These ethnocentric attitudes alter the communication and cooperation between different ethnic groups. Scholars have indicated that in societies with high levels of ethnocentrism, it is more challenging to maintain cohesion and solidarity between all group members [8] (Sniderman, Peri, De Figueiredo \& Piazza, 2002).

The more serious negative aspects of ethnocentrism have often been manifested through history as violent conflicts, wars, slavery, ethnic cleansing, and genocide. The protohistorical accounts of conflict were based on tribal affiliations. The crusade in the Middle Age, conflicts in Northern Ireland, and Nazi holocaust were based religion. In addition to tribal and religious basis of ethnocentrism, race, colonialism, and ethno nationalism have contributed toward distinctly negative and same time's savage consequences (https: www.euroform healthcare.biz/mentalhealth-21 causesconsequences and-reduction of ethnocentrism: html, Brewer \& Campbell, [9]). The other problem of ethnocentrism is regarding violence and crime. An ethnocentric is capable of violence and other forms of crime towards members of other ethnic groups he/ she holds to be "inferior" and can easily support the use of force to dogmatically maintain their "superior" belief [10].

According to Aquiline [11] ethnocentrism is also the root cause of the phenomenon of ethno-political competition, discrimination, and violence in several of the so called 'weak' or 'collapsed' states. Some of the manifestations of ethnocentrism commonly found in the 'weak' or 'collapsed' states are citizenship crisis, lack of political consensus, economic insecurity, lack of an agreed up on concept of the common good [11]. According to the research conducted by Demewoz [12] on college students of Ethiopia, the results show that national feeling, unity, helping and cooperative behaviours may be endangered, national agenda narrowed and replaced by ethnic agenda. As a result, ethnic tension, violence and conflict may prevail. This problem may make it difficult to create a stable government.

Ethiopia consists of more than 80 ethnic groups with their own languages, heritage, and areas of settlement [12]. Today, and presently in Ethiopia, many ethnocentric people prefer to identify with their various ethnics and family, then being called Ethiopians. They rather prefer, you identify them first as their ethnic groups like Amhara, Oromo, Wolayita, Kembata, Hadiya, Halaba, etc. The endpoint of such consequences is that the people may never believe in or have an idea of the "concept of a nation". Issues of this nature, that has to do with the people been totally and wholly connected to their ethnics, portends, and has always signify a great failure for the nation's political system, and in all other brotherly aspects of a nation. In Ethiopia, the political atmosphere is presently lined towards ethnic identities. There is tension, from all sides of the regional states. These have led to, loss of life, property destruction, breakdown of marriages, ethnic cleansing, loss of job, and even crises between federal government and regional government because of their polarized ethnocentric attitude. This has eventually, becoming as a barrier for a national solidarity, harmony, and national identity.

Regarding study area, there are more ethnic groups living together. There were ethnic based attitudes and conflicts among these ethnic identities. Ethnic cleansing and loss of job are common. In study area, nowadays it is common to see conflict in foot ball and other matches/ stadiums because of ethnocentric attitudes. Many were injured, properties were destructed and life was lost. There are ethnic conflicts on cultural and natural resources. Churches were burnt because of religious egocentrism. Sometimes even employment is practiced along with ethnic lines. Placement of leaders on positions at federal, regional and zonal level is sometimes becoming ethnic based not standard based. Because of administrative restructuring and self determination questions political instability is becoming regular and it was aggravated by ethnic attitudes. There are unfavourable development competitions among ethnic groups motivated by ethnic attitudes. Ethnic based speeches on social media which look in group as special and out group as inferior are being flourished. Individuals are using face book and fake accounts based on their ethnic identity or ethnic groups. These pages stress solely on superiority of in-group not the strong relationship among ethnic groups. These and other observed problems motivated the researchers to conduct this study.

This study also addressed the research gaps of literature review. Some of the previous research have suggested the effects of ethnocentrism in other countries and Ethiopia. To mention, Njoroge and Krori (2013) identified the significance and effects of ethnocentrism on Kenyan society. Gudykunst [13]; Harris \&Jonson [14], Jandt, [15] also identified the consequences of ethnocentrism. These studies were conducted to identify the effects of ethnocentrism. No studies conducted on the aggravating variables of ethnocentrism. Mekonnen Hailemariam [16] \& Demewoz [12] also conducted research on the impacts of ethnocentrism on Ethiopian higher education students. They did not address regarding the factors leading to ethnocentrism, and 
they focussed on higher education students and did not address the other employees who can be parents, friends, relatives and socializing factors to ethnocentric attitudes. Most researchers, for instance, Chandra Muzaffar [17] \& Kellow \& Steeves, [18] identified media particularly social media and radio as a tool to promote ethnocentric attitudes. But this study will identify the other tools or mediums promoting ethnocentrism in Ethiopia. Old studies conducted by Beswick \& Hill, 1969; 1972; Card, Dustman \& Preston, 2003; Goot \& Watson, 2001; Ho, Niles, Penney \& Thomas, 1994) make clear that social conditions such as social class, age, education level, religious orientation, and gender may be factors predictive of ethnocentric attitudes to ethnic groups There is research gap of new studies regarding these demographic variables. Considering the above issues, this study will explore the causes, effects, and mediums of ethnocentrism in selected zones of South Nation Nationalities and Peoples Regional state of Ethiopia in order to provide some recommendations for the harmony and solidarity among ethnic groups. Therefore, the study was intended to answer the following research questions.

a) What are the main causes of ethnocentric attitudes?

b) What are the effects of ethnocentrism on the society?

c) What mediums are being used to spread the ethnocentric attitudes?

d) Is there statistically significant difference among demographic characteristics (sex, age, educational level, and marital status) of respondents on ethnocentric attitudes?

\section{Research Methodology}

\section{Research Design}

A descriptive survey design was used to collect data from employees working in public offices in selected zones of South Nations Nationalities and Peoples Region. A survey use questionnaire to gather data about particular topic and it is usually being used to identify the relationship between variables.

\section{Target Population}

The target population of this study included employees from the three selected zones of the South Nation, Nationalities and People's Regional State (SNNPR) of Ethiopia as to the information from public service and Human Resource Development office of each zone, there were 9732 employees, serving in the selected zones, from which 6222 were males and 3510 were females. From the researcher's observation and based on the information presented, 3 zones were selected purposefully; in which problem of ethnocentrism has been frequently observed in social medias, foot ball stadiums, and indifferent social interactions and the impact is vital. Therefore, the participants of the study in these 3 selected zones were 2377 employees (i.e.1676 males and 701 females). Thus, the total number of participants was 2377 employees.
Sample sizes were estimated by using Levin's formula of Israel (1992) and Krejcie and Morgan (1970) sample determination techniques. Accordingly, assuming the population $(\mathrm{N})$ of selected offices of Kembata Tembaro zone employees 2377, the required sample size at $95 \%$ level of confidence and a maximum discrepancy (e) of $5 \%$ of the total population, the sample size was determined by using the formula. Hence, the sample sizes for the study is 343 employees.

\section{Data Sources and Data Gathering Instruments}

As this study is basically empirical in nature, the researcher gathered primary data from employees to answer the basic research questions. Hence, more emphasis was given to the primary data source. Therefore, the researcher used both questionnaire and focus group discussion to collect necessary data. The researcher used closed- ended questionnaire which were designed on lickert scale of measurement basis to collect primary data, so that the variables could be ranked to measure the degree of their strength or the agreement or the disagreement of the respondents with the variables. By referring other researches (Mekonnen Hailemariam [16] and Demewoz [12]) and review of related literature questionnaires were prepared about causes and effects of ethnocentrism. Open ended questions were also prepared to gather further information regarding the causes and effects of ethnocentrism on the society.

This study also employed Neuliep \& McCroskey's [19] generalised ethnocentrism (GENE) scale for measuring ethnocentric attitudes. The questionnaire's five items with five point Likert scale (strongly agree to strongly disagree) indicated high reliability ( $\alpha=0.85$ ). The GENE scale has demonstrated acceptable reliability in previous studies (Dong, Day \& Colloço, 2008; Justen, 2009; Swenson \& Visgatis, 2012 as cited in Neuliep $\&$ McCroskey's [19]. These questions were employed to measure ethnocentric attitude of the study participants.

Besides to 343 samples selected for quantitative questionnaire and for the qualitative questionnaires FGD was conducted one session with 23 leaders by using additional time besides with their routine discussion session. The discussion focused on the issues like causes and effects of ethnocentrism, and the mediums of ethnocentrism (the mechanisms that ethnocentric attitude can be spread). The researcher used this tool to strengthen the validity of the study so as to come up with the drawbacks of closed ended questionnaires (Lewin, 2005; Biggam, 2008).

\section{Method of Data Analysis}

After collecting relevant data by using both questionnaires, it was necessary to utilize statistical techniques to analyze the information. Therefore, the survey data was processed by using a SPSS (version 20). The researcher used frequency tables to summarize the respondents profile in the form of frequency, percentages, and mean. Descriptive statistical measures 
(frequency, percentage, and mean scores) used to describe the general pattern of the respondents in line with the socio demographic backgrounds, the major causes of ethnocentrism, the effects of ethnocentrism, and also the mediums used to spread ethnocentric attitudes. To analyze the qualitative responses, the researcher clustered similar words or phrases into categories, themes, or a finding that was later used to detect frequency, interrelationship, and grounded theory development (Saldana, 2011; Merriam, 2009). Independent sample t-test was used to analyze sex difference between male and female employees in their ethnocentric attitude. Analysis of variance (ANOVA) is a statistical test that was employed to analyze the difference among group means on the basis of the employees' demographic details (age, educational level, and marital status).

\section{Result and Discussion}

\section{The Causes of Ethnocentrism}

Table 1: Summary of percentage, mean, and standard deviation values of causes of ethnocentrism.

\begin{tabular}{|c|c|c|c|c|c|c|c|c|c|c|c|c|}
\hline No. & Causes of Ethnocentrism & SA(5) & & $A(4)$ & & NS(3) & & DA(2) & & $\operatorname{SD}(1)$ & & \\
\hline & \multirow{2}{*}{ Biological Causes } & $\mathbf{F}$ & $\%$ & $\mathbf{F}$ & $\%$ & $\mathbf{F}$ & $\%$ & $\mathbf{F}$ & $\%$ & $\mathbf{F}$ & $\%$ & Mean \\
\hline & & & & & & & & & & & & 2.5 \\
\hline 1 & Nature or heredity & - & - & - & - & 55 & 16 & 152 & 44.3 & 136 & 39.7 & 1.8 \\
\hline 2 & Aggression & 163 & 47.5 & 63 & 18.4 & 59 & 17.2 & 58 & 16.9 & - & - & 4 \\
\hline \multirow[t]{2}{*}{3} & Vulnerability to disease & - & & - & & 10 & 2.9 & 213 & 62.1 & 120 & 34.9 & 1.8 \\
\hline & Psychological Causes & & & & & & & & & & & 3.26 \\
\hline 4 & Narcissism & 103 & 30 & 159 & 46.4 & 15 & 4.4 & 52 & 15.2 & 14 & 4.1 & 3.8 \\
\hline 5 & Religious fundamentalism & - & - & 83 & 24.2 & 17 & 4.9 & 143 & 41.7 & 100 & 29.2 & 2.2 \\
\hline 6 & Personality traits & 99 & 28.9 & 58 & 16.9 & 90 & 26.2 & 40 & 11.7 & 56 & 16.3 & 3.3 \\
\hline 7 & Intolerance for ambiguity & 63 & 18.4 & 95 & 27.7 & 43 & 12.5 & 120 & 34.9 & 22 & 6.4 & 3.2 \\
\hline \multirow[t]{2}{*}{8} & Parental authoritarianism & 101 & 29.4 & 133 & 38.8 & 28 & 8.2 & 59 & 17.2 & 22 & 6.4 & 3.8 \\
\hline & Sociological Causes & & & & & & & & & & & 3.4 \\
\hline 9 & $\begin{array}{l}\text { A strong identification with the } \\
\text { in-group of the actor }\end{array}$ & 193 & 56.3 & 150 & 43.7 & - & - & - & - & - & - & 4.7 \\
\hline \multirow[t]{2}{*}{10} & $\begin{array}{l}\text { Polarization with outsid- } \\
\text { er-group member }\end{array}$ & - & - & - & - & 63 & 18.4 & 233 & 67.9 & 47 & 13.7 & 2.1 \\
\hline & Political causes & & & & & & & & & & & 4.1 \\
\hline 11 & $\begin{array}{l}\text { Inspiration of ethnic political } \\
\text { leaders }\end{array}$ & 139 & 40.5 & 162 & 47.2 & 2 & 0.6 & 40 & 11.7 & - & - & 4.1 \\
\hline 12 & $\begin{array}{c}\text { Agenda of ethnic political } \\
\text { parties }\end{array}$ & 69 & 20.1 & 192 & 55.9 & 82 & 23.9 & - & - & - & - & 4 \\
\hline \multirow[t]{2}{*}{13} & $\begin{array}{l}\text { Political leaders advocating } \\
\text { ethnic interests rather than } \\
\text { national interest }\end{array}$ & 122 & 35.6 & 173 & 50.4 & 42 & 12.2 & 6 & 1.7 & - & - & 4.2 \\
\hline & Economic Causes & & & & & & & & & & & 2.95 \\
\hline 14 & $\begin{array}{l}\text { Conflict between ethnic groups } \\
\text { competing for scarce resources } \\
\text { in society }\end{array}$ & - & & - & & - & & 298 & 86.9 & 45 & 13.1 & 1.9 \\
\hline 15 & $\begin{array}{l}\text { Considering outsiders as a } \\
\text { threat to their own social posi- } \\
\text { tion (eg. In the labour or house } \\
\text { markets) }\end{array}$ & 163 & 47.5 & 103 & 30 & 20 & 5.8 & 33 & 9.6 & 24 & 6.9 & 4 \\
\hline
\end{tabular}

In order to identify the main causes of ethnocentrism and which causes are serious in Ethiopia percentage, mean, and standard deviation were employed. Participants were asked to rate the causes of ethnocentrism. Table 1 shows the frequency, percentage, and mean of their ratings of the causes of ethnocentrism. As it is indicated in the table, political factors are 
the most serious causes of ethnocentric attitudes (the mean value is 4.1). . As it is indicated in the table 1, advocating ethnic interests rather than national interest by political leaders, inspiration of political leaders, and agenda of ethnic political parties were rated as the most serious effects each by mean values of $(4.2,4.1$, \&4.0) which have been the source of ethnocentrism. Sociological causes which are a strong identification with the in-group of the actor (mean=4.7) was the other strong cause of ethnocentric attitude. Aggression (mean=4.0) from biological cause, narcissism (mean=3.8) and Parental authoritarianism (mean=3.8) from psychological causes were serious causes of ethnocentric attitude. This shows that ethnocentrism has different causes that affected the attitude of in-groups towards out-group.

The result of focus group discussion revealed that perception of background history is the main cause of ethnocentrism. This can be viewed in two ways. The first is that one ethnic group accept that it was discriminated and dominated by the other ethnic group. This caused negative feeling for the out-group. The second perspective is that considering own ethnic group has superior ethnic history. They considered themselves as superior to other on every aspect of life. This caused unfavourable competition among ethnic groups. The other cause was struggle for power by aggravating ethnic issues by leaders who want to nominate their ethnic group. These kinds of leaders even attribute their failure to their ethnic group to gain support from ethnic groups. Political and economic domination by one or two ethnic groups also caused negative attitude towards them.

In line with this finding, Aquiline, 2008 and Cohen, 1981 found politization of ethnic identities was dangerous cause ethnocentrism. Wilson [20] suggested that ethnocentric tribal groups may have a biological advantage due to aggression and other related behaviours, bringing success to groups that divide the world between "us" and "them." Researchers have also shown an association between ethnocentrism and a range of psychological variables including narcissism, religious fundamentalism, personality traits, intolerance for ambiguity, and authoritarianism [21]. According to Hooghe, [22] social identity approaches assume that ethnocentrism is the result of a strong identification with the in-group of the actor, which almost automatically leads to negative feelings toward and stereotyping of members of the out group.

\section{The Effects of Ethnocentrism}

Table 2: Summary of percentage, mean, and standard deviation values of effects of ethnocentrism.

\begin{tabular}{|c|c|c|c|c|c|c|c|c|c|c|c|c|}
\hline No. & Items & S A & & A & & NS & & D & & S D & & Mean \\
\hline 1 & & $\mathbf{F}$ & $\%$ & $\mathbf{F}$ & $\%$ & $\mathbf{F}$ & $\%$ & $\mathbf{F}$ & $\%$ & $\mathbf{F}$ & $\%$ & \\
\hline & Making false assumptions about others & 218 & 63.6 & 103 & 30 & 8 & 2.3 & 14 & 4.1 & - & - & 4.5 \\
\hline 2 & Violent conflicts & 13 & 3.8 & 92 & 26.8 & 6 & 1.7 & 161 & 46.9 & 72 & 20.9 & 2.7 \\
\hline 3 & Ethnic cleansing & 102 & 29.7 & 194 & 56.6 & 1 & 0.3 & 46 & 13.4 & - & - & 4 \\
\hline 4 & Loss of life & 93 & 27.1 & 113 & 32.9 & 19 & 5.5 & 66 & 19.2 & 52 & 15.2 & 3.4 \\
\hline 5 & Loss of property & 219 & 63.8 & 88 & 25.7 & - & - & 26 & 7.9 & 10 & 2.9 & 4.4 \\
\hline 6 & $\begin{array}{l}\text { Superiority on social, political and economic } \\
\text { affairs of in-group }\end{array}$ & 212 & 61.8 & 96 & 27.9 & 2 & 0.6 & 33 & 9.6 & - & - & 4.4 \\
\hline 7 & $\begin{array}{c}\text { Problems in political struggles and distribution } \\
\text { of resources }\end{array}$ & 84 & 24.5 & 88 & 25.7 & 92 & 26.8 & 40 & 11.7 & 39 & 11.4 & 3.4 \\
\hline 8 & $\begin{array}{l}\text { Barrier to effective and impressive intercultural } \\
\text { communication }\end{array}$ & 109 & 31.8 & 159 & 46.4 & 75 & 21.9 & - & - & - & - & 4.1 \\
\hline 9 & $\begin{array}{l}\text { National agenda narrowed and replaced by } \\
\text { ethnic agenda }\end{array}$ & 229 & 66.8 & 73 & 21.3 & - & - & 23 & 6.7 & - & - & 4.3 \\
\hline
\end{tabular}

Table 2 above shows the frequency, percentage and the mean value of the effect of ethnocentrism on the society. As it is indicated in the table 2, national agenda narrowed and replaced by ethnic agenda was rated as the most serious effects of ethnocentrism and this illustrates that $66.8 \%$ of the respondents strongly agreed with this statement. Ethnocentrism is leading to property loss. $63.8 \%$ strongly agreed, $25.7 \%$ agreed, $7.9 \%$ disagreed, and $2.9 \%$ strongly disagreed. Making false assumptions about others (63.6\%) was the other serious effect of ethnocentrism. Superiority on social, political and economic affairs of in-group, barrier to effective and impressive intercultural communication, ethnic cleansing, and loss of life each by $(61.8 \%, 31.8 \%, 29.7 \%, 27.1 \%)$ were rated which have been negatively affecting the out-groups. Moreover, responses of focus group discussion revealed that identifying and supporting persons based on their ethnic identity, identifying oneself and worrying about ethnic superiority, ignoring others, and national narrowness are the main effects ethnocentrism which in turn disturbs the psychological, social, political, and 
economic life of the society. The other effects of ethnocentrism were every day minor conflicts, employment bias, relationship only with own ethnic group members, psychological effects like fear, depression, hopelessness, even suicidal ideation, and ethnic cleansing. Similarly, the research conducted by Demewoz [12] on college students of Ethiopia, show that national feeling, unity, helping and cooperative behaviours may be endangered, national agenda narrowed and replaced by ethnic agenda. According to Barger [23] ethnocentrism is the tendency of making false assumptions about others' ways of life based on own limited experience. In addition, research conducted by Mustapha et al. [7] reveal that ethnocentrism has been the most constant social problem in Malaysia and as such, living together in a harmonious society with different ethnic backgrounds, culture, language, and religion has not been easy for society.

\section{The Mediums of Ethnocentrism}

As indicated in the table, high proportion (90.6\%, 89.3\%, $87.7 \%, 85.1 \%$, and $62.1 \%$ ) of the employees' respondents showed either agreement or strong agreement with the statements in item no $9,8,7,1$, and 2 of table 3 , which have a positive statement about the assumption of mediums ethnocentrism. This shows that employees were agreed with the concepts that ethnocentric attitudes were speeded by wrong use of agenda of ethnic parties, ethnic federalism, social media, ethnic literatures, and ethnic based sport clubs.

Table 3: Summary of percentage, mean, and standard deviation values of mediums of ethnocentrism

\begin{tabular}{|c|c|c|c|c|c|c|c|c|c|c|c|c|}
\hline No & Items & \multicolumn{2}{|c|}{$S \mathrm{~A}(5)$} & \multicolumn{2}{|c|}{$A(4)$} & \multicolumn{2}{|c|}{ Not Sure(3) } & \multicolumn{2}{|c|}{ Dis Agree(2) } & \multicolumn{2}{|c|}{$S \mathrm{D}(1)$} & \multirow[t]{2}{*}{ Mean } \\
\hline & & $\mathbf{F}$ & $\%$ & $\mathbf{F}$ & $\%$ & $\mathbf{F}$ & $\%$ & $\mathbf{F}$ & $\%$ & $\mathbf{F}$ & $\%$ & \\
\hline 1 & Ethnic literature & 169 & 49.2 & 123 & 35.9 & 33 & 9.6 & 10 & 2.9 & 8 & 2.3 & 4.3 \\
\hline 2 & Ethnic sport clubs & 104 & 30.3 & 109 & 31.8 & 69 & 20.1 & 41 & 11.9 & 20 & 5.8 & 3.7 \\
\hline 3 & Distinct mode of dressing & 60 & 17.5 & 68 & 19.8 & 193 & 56.3 & 22 & 6.4 & - & - & 3.5 \\
\hline 4 & Ethnic music & 62 & 18.1 & 93 & 27.1 & 102 & 29.7 & 40 & 11.7 & 46 & 13.4 & 3.3 \\
\hline 5 & $\begin{array}{l}\text { Socialization through family, schools, peer } \\
\text { groups, and religious teachings }\end{array}$ & 89 & 25.9 & 105 & 30.6 & 65 & 18.9 & 56 & 16.3 & 28 & 8.2 & 3.5 \\
\hline 6 & Electronic media (television, radio) & 46 & 13.4 & 39 & 11.4 & 213 & 62.1 & 25 & 7.3 & 20 & 5.8 & 3.2 \\
\hline 7 & Social media (face book, you tube, etc) & 208 & 60.6 & 93 & 27.1 & 13 & 3.8 & 12 & 3.5 & 17 & 4.9 & 4.5 \\
\hline 8 & Ethno-politics /ethnic federalism & 198 & 57.8 & 108 & 31.5 & 29 & 8.5 & 8 & 2.3 & - & - & 4.5 \\
\hline 9 & Ethnic parties agenda & 208 & 60.6 & 103 & 30 & - & - & 20 & 5.8 & 12 & 3.5 & 4.4 \\
\hline 10 & $\begin{array}{l}\text { Ethnic political leaders/public figures } \\
\text { speech }\end{array}$ & 99 & 28.9 & 98 & 28.8 & 90 & 26.2 & 62 & 18.1 & 64 & 18.7 & 3.9 \\
\hline
\end{tabular}

The data obtained through focus group discussion indicated that majority of participants had a perception of ethnic parties' intention, ethnic federalism (mainly the understanding of leaders and their followers), and ethnic literature and history consciousness as the main tools to spread ethnocentric attitudes. The speech of ethnic leaders, public figures, and even some elites on different media mainly social media are becoming critical in spreading ethnocentrism. Language and cultural symposiums were sometimes becoming mediums of ethnocentrism because they only focused on superiority of own ethnic group. Consistent with this finding Mulanik \& Mercy Muthoni [24] identified that ethno-politics is central to the country's ethnic conflicts and that ethnocentric attitudes. In addition, the research conducted by Bitwoded Admasu Dagnaw (2014) revealed that as result of ethnic federalism there is ethno-centrism and a sense of superiority and making other ethnic groups inferior to other and generally the ethnic federalism affects interaction and makes individuals to be separated one ethnic group from the other $[25,26]$.

\section{Comparison of Gender Differences Regarding Employees' Loyalty}

An independent-one sample T-test was used to analyze the differences in the scores on employees' loyalty among employees of different gender. Table 4 shows that there is mean difference in the ethnocentrism score for male $(M=34.70, S D=5.350)$ than female $(M=31.01, S D=4.734)$. This difference was statistically significant as obtained by $\mathrm{t}(341)=6.014, \mathrm{p}<0.05$. The result shows that males are more ethnocentric than females. The magnitude of the difference was small (eta squared $=0.096$ ). This means $9.6 \%$ of variance in employees' ethnocentrism explained by gender. This implies that employees' ethnocentrism varies on account of their sex. This finding is supported by a research result conducted by Sidanius, Pratto and Brief (1995) as cited in Jack; David 0.; Christopher; \& Cara (2001) looking at respondents from Australia, Sweden, United States and Russia, found that males had higher levels of ethnocentrism $[27,28]$. 


\section{Psychology and Behavioral Science International Journal}

Table 4: Summary of independent sample T-test that compares male and female employees regarding employees' loyalty.

\begin{tabular}{|c|c|c|c|c|c|c|c|c|}
\hline Scale & Group & N & Mean & SD & df & t & P-Value & Effect Size \\
\hline & Female & 101 & 31.01 & 4.734 & 341 & 6.014 & 0 & 0.096 \\
\hline Ethnocentrism & Male & 242 & 34.7 & 5.35 & & & \\
\hline \multicolumn{7}{|c|}{ Significant at the 0.05 level } \\
\hline
\end{tabular}

\section{Comparison of Demographic Characteristics (Age, Educational Level, Work Experience, and Sectors) Regarding Employees' Loyalty}

Table 5: Summary of the ANOVA results of demographic variables (age, educational level, and marital status).

\begin{tabular}{|c|c|c|c|c|c|c|c|}
\hline Source of Variation & Sum of Square & Df & $\begin{array}{c}\text { Mean } \\
\text { Squares }\end{array}$ & $\mathbf{F}$ & $\mathbf{P}$ & & $\begin{array}{c}\text { Effect Size/Eta } \\
\text { Square }\end{array}$ \\
\hline \multirow[t]{3}{*}{ Age } & Between Groups & 635.967 & 3 & 211.989 & 7.586 & 0 & 0.063 \\
\hline & Within Groups & 9473.462 & 339 & 27.945 & & & \\
\hline & Total & 10109.429 & 342 & & & & \\
\hline Source of variation & sum of square & Df & Mean Squares & $\mathrm{F}$ & $\mathrm{p}$ & effect size eta square & \\
\hline \multirow[t]{3}{*}{ Educational level } & Between Groups & 935.346 & 3 & 311.782 & 11.521 & 0 & 0.093 \\
\hline & Within Groups & 9174.083 & 339 & 27.062 & & & \\
\hline & Total & 10109.429 & 342 & & & & \\
\hline Source of variation & sum of square & Df & Mean Squares & $\mathrm{F}$ & $\mathrm{p}$ & effect size eta square & \\
\hline \multirow[t]{3}{*}{ Marital status } & Between Groups & 307.669 & 2 & 153.835 & 5.336 & 0.05 & 0.03 \\
\hline & Within Groups & 9801.759 & 340 & 28.829 & & & \\
\hline & Total & 10109.429 & 342 & & & & \\
\hline \multicolumn{8}{|c|}{ Significant at the 0.05 level } \\
\hline
\end{tabular}

One-way ANOVA was used to test whether there are significance differences between the means of demographic characteristics on employee loyalty. As Table 5 shows, there is not a statistically significant difference in the scores on employees' ethnocentric attitude among employees of different age level $(\mathrm{F}=7.586, \mathrm{p}<0.05)$. This tells us that employees' ethnocentric attitude varies on account their age level differences. Table 5 also shows that there is a statistically significant difference in the scores on employees' ethnocentrism among employees of different educational level $(\mathrm{F}=11.521, \mathrm{p}<0.05)$. This tells us that employees' ethnocentrism varies on account their educational level differences. As Table 5 also shows, there is a statistically significant difference in the scores on employees' ethnocentrism among employees from different marital status $(\mathrm{F}=5.336, \mathrm{p}<$ .05. But post hoc result illustrates that there is no statistically significant difference in the scores on employees' ethnocentrism among employees from different age, educational level, and marital status. This is because of mean differences and standard deviation differences are small.

\section{Conclusion and Recommendations}

\section{Conclusion}

As explained in results, political factors are the most serious causes of ethnocentric as it is indicated in the result, advocating ethnic interests rather than national interest by political leaders, inspiration of political leaders, and agenda of ethnic political parties were rated as the most serious cause of ethnocentrism. Sociological cause which is a strong identification with the ingroup of the actor was the other strong cause of ethnocentric attitude. Aggression from biological cause, narcissism and Parental authoritarianism from psychological causes were serious causes of ethnocentric attitude. This shows that ethnocentrism has different causes that affected the attitude of in-groups towards out-group.

As it is indicated in the result, national agenda narrowed and replaced by ethnic agenda was rated as the most serious effects of ethnocentrism. Ethnocentrism is also leading to property loss in the country. In addition, making false assumptions about others is becoming serious effect of ethnocentrism. Superiority on social, political, and economic affairs of in-group, barrier to effective and impressive intercultural communication, ethnic cleansing, and loss of life have been negatively affecting the outgroups. Moreover, responses of focus group discussion revealed that identifying persons based on their ethnic identity, identifying oneself and worrying about ethnic superiority, ignoring others, and national narrowness are the main effects ethnocentrism which in turn disturbs the psychological, social, political, and economic life of the society.

There is statistically significant difference on ethnocentrism among employees of different sex. That is males are more ethnocentric than female employees. There is statistical difference 
on scores of ethnocentrisms among employees of different age groups, educational level, marital status and sectors. But the result of pot hoc indicates that there is no statistical difference because of small difference of mean and standard deviation. This indicates that employees' ethnocentric attitude does not vary because of employees' demographic characters.

\section{Recommendations}

Regarding to the presentstudy, the following recommendations forwarded for leaders, organizations, and government. The current research work gives investigational confirmation of the causes, effects and mediums of ethnocentrism. Therefore, leaders, organizations, and government should work on these factors to increase solidarity of the society. Organizations should pay more attention to improving leaders', and employees' attitude towards out-groups. Some strategies plans need to be developed in those organizations in order to increase the relationship of ethnic groups further. This information could be used to help develop strategies and meet the needs of society through national attitude development. The government of Ethiopia especially Ministry of Peace should participate concerned stake holders like Universities, colleges, religious institutions, and etc. Future research should focus on the sample size, influences of personality on the perception of others, and other factors that would affect employees' attitude like empowerment, policy, work environments, rewards by politicians etc.

\section{References}

1. Raha R (2013) Komunikasi Efektif Melalui Media Perantaraan dalam Kalangan Masyarakat Melayu: satu kajian kes di Melaka/Raha Radzi. In: Prosiding Seminar Penyelidikan Pemikiran dan Kepimpinan Melayu 2013. Institut Pemikiran dan Kepimpinan Melayu (IMPAK), Shah Alam, pp. 43-57.

2. Njoroge MW, Kirori GN (2014) Ethnocentrism: Significance and effects on Kenyan society. African Journal of Political Science and International Relations 8(9): 356-367.

3. Syed HA (2008) Ethnic Relations in Malaysia. Harmony and Conflicts. Strategic Information and Research Development Centre (SIRD), Petaling Jaya, Malaysia.

4. Sumner WG (1906) Folkways: A study of the sociological importance of usages, manners, customs, mores, and morals. Ginn \& Co, New York, USA.

5. Jusang B, Ezhar T, Wan AWA (2008) Kejelekitan Sosial dan Hubungan Interpersonal Antara Kaum dalam Komuniti Maya Melalui Internet Relay Chat (IRC). In Akmar Hayati, USA.

6. Mohd RTA (2011) Nasib Melayu di Bumi Melayu. Cheras: Utusan Publications \& Distributors Sdn Bhd, India.

7. Mustapha R, Azman N, Karim F, Ahmad AR, Lubis MA, et al. (2009) Social integration among multi-ethnic students at selected Malaysian universities in peninsular Malaysia: A survey of campus social climate. ASEAN Journal of Teaching and Learning in Higher Education 1(1): 3544.

8. Hooghe M (2003) Value congruence and convergence within voluntary associations: Ethnocentrism in Belgian organizations. Political Behavior 25(2): 151-175.
9. Brewer, Marilynn B, Campbell DT (1976) Ethnocentrism and Intergroup Attitudes: East African Evidence. Sage Publications, USA.

10. Yieke FA (2008) The discursive construction of ethnicity: the case of the 2007 Kenya general election. $12^{\text {th }}$ General Assembly, Codersia, Senegal.

11. Aquiline TSJ (2008) politization of ethnic identities and the common good in Kenya. text of a talk delivered April 2 at noon presentation on Kenya, the common good and the politization of ethnic identities.

12. Demoze A (2006) Ethnocentrism among four ethnic groups of students, Implications and Future Direction: The Case of Dilla College of Teacher Education and Health Sciences. Organization for Social Science Research in Eastern and Southern Africa (OSSREA).

13. Gudykunst WB, Lee C (2003) CCC Theories. In: Gudykunst (Ed.), CrossCultural and Intercultural Communication. Thousand Oaks, SAGE, USA.

14. Harris M, Johnson $O$ (2007) Cultural Anthropology. Pearson Education, New York, USA.

15. Jandt FE (2001) Intercultural communication: An introduction. Thousand Oaks, SAGE, USA.

16. Mekonnen HZ (2013) The Impacts of Ethnocentrism and Stereotype on Inter-Cultural Relations of Ethiopian Higher Education Students. Online Journal of Communication and Media Technologies 3(4): 126148.

17. Chandra Muzaffar (2010) Malaysia Kini.

18. Kellow C, Steeves H (1998) The role of radio in the Rwandan genocide. Journal of Communication 48(3): 107-128.

19. Neuliep JW, McCroskey JC (1997) The development of a U.S. and generalized ethnocentrism scale. Communication Research Reports 14(4): 385-398.

20.Wilson EO (1978) On human nature. Harvard University Press, Cambridge, UK.

21. Keith KD (2011) Ethnocentrism. In: Keith KD(Ed.), Cross-cultural psychology: Contemporary themes and perspectives. Wiley-Blackwell, Malden, United States, pp. 20-33.

22. Hooghe M (2008) Ethnocentrism. In: Darity WJ (Ed.), In: ( $2^{\text {nd }}$ edn.), International encyclopedia of the social sciences Detroit, MI: Macmillan Reference USA.

23. Bager K (2008) Ethnocentrism: Recognition and control of behaviour, both our own others.

24. Mulanik, Mercy M (2011) A phenomenological study of ethnicity, and ethnocentrism and conflict management strategies in independent Kenya. Kenyatta university institutional repository, Kenya.

25. Bitwoded AD (2014) Ethiopian Ethnic Federalism and its Implications for University Students: The Case of University of Gondar. Department of Civics and Ethical Studies, University of Gondar, College of Social Sciences and Humanities, Ethiopia.

26. Cohen A (1981) The politics of elite culture: explanations in the dramaturgy of power in a modern African society. University of California Press, Berkeley, California, USA.

27. Goot M (1993) Multiculturalists, Monoculturalists, and the many in between: Attitudes to cultural diversity and their correlates. Australian and New Zealand Journal of Sociology 29(2): 226-253.

28. Mosher DL, Scodel A (1960) Relationships between ethnocentrism in children and the ethnocentrism and authoritarian rearing practices of their mothers. Child Development 31: 369 - 376. 


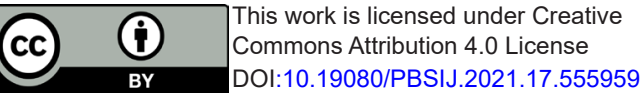
Your next submission with Juniper Publishers
will reach you the below assets

- Quality Editorial service

- Swift Peer Review

- Reprints availability

- E-prints Service

- Manuscript Podcast for convenient understanding

- Global attainment for your research

- Manuscript accessibility in different formats ( Pdf, E-pub, Full Text, Audio)

- Unceasing customer service

Track the below URL for one-step submission https://juniperpublishers.com/online-submission.php 